
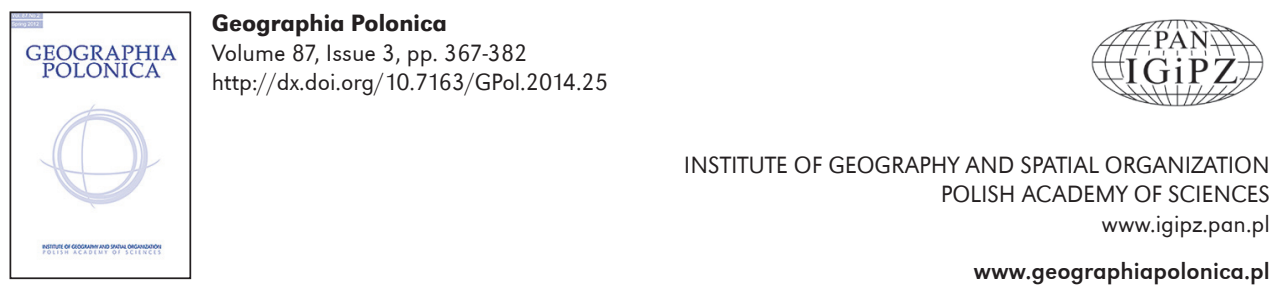

\title{
THE ENDURING CONNECTION BETWEEN GENDER, MIGRATION AND HOUSEHOLD SERVICES
}

\author{
Josefina Domínguez-Mujica \\ Chair of the IGU Commission on Global Change and Human Mobility \\ University of Las Palmas de Gran Canaria \\ C/Pérez del Toro 1, 35003 Las Palmas: Spain \\ e-mail: josefina.dominguezmujica@ulpgc.es
}

\begin{abstract}
The expanding literature analysing the way in which gender shapes migration highlights the high level of demand for migrant women to render household services in Southern Europe. However, while studies assessed the characteristics of the phenomenon during the expansion phase to the economic cycle, it was unclear what the situation in times of uncertainty would be, and what consequences this would have for migration regulations and the labour market. The work described in this article sought to respond to the above questions by exploring more fully the enduring connection between gender, migration and household services in Spain, and by analysing the role and consequences of the statuses of immigrant women as regards invisibility and irregularity.
\end{abstract}

\section{Key words}

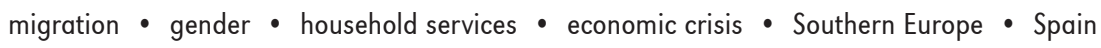

\section{Introduction}

The work documented in this paper has focused on the connections between gender, migration and household services during the economic cycle of expansion and contraction undergone by Spain, a European country manifesting a high rate for female immigrants employed in domestic work. The purpose of the research has been to contribute to the debate on how the perspective on gender as regards the migrations of domestic workers and caregivers can be conceptualised most effectively, and on the role the legal context has played in regulating the sector in question during the stages of economic expansion and recession.

The gender perspective as regards migration: a subject for analysis since the 1980s

While human migrations have been a constant phenomenon throughout history, certain of the changes affecting them are seen to be of very recent origin. Some of these 
relate to the increasing 'feminization' of international migrations, a post-industrial phenomenon that coincides with the changing roles of migratory processes. The last few decades have seen a growing number of women pursuing migratory projects of their own that are independent of those involving men (be these husbands, fathers, or whatever). This is to say that, while female international migrations were also important objects of study in the past, the recent differentiation of the profile has been sufficient to encourage the development of a theoretical body of research that is quite new in character. What is more, the factor in question has run parallel with the emerging gender perspective in the social sciences, ensuring that a new framework for analysis has arisen in the form of the gender perspective on migration - a flourishing field of study since the 1980s.

It was in the 1980s that certain authors came to a conclusion that the incorporation of migrant women into the labour force had to be seen within the context of progressing deindustrialization of post-crisis economies in developed countries; the dislocation of vertically concentrated, unionised factories; and an increase in the number of small production units which locate their labour through informal networks. In this context, unpaid work done by women as both home workers and domestic workers is seen to subsidise the modern sector (Pessar 1984). The incorporation of women into wage employment has in turn been interpreted in terms of both gains and losses. It might lead to greater exploitation, but it does at the same time favour female independence, and perhaps also a greater awareness of the fact that the conditions experienced by women are not a matter of fate, but are rather there to be changed and capable of being changed (Morokvasic 1984).

As time went by, the literature on migration among women has come to examine the way in which gender shapes the migratory process, as well as the degree to which the economic, social and political consequences of the phenomenon are of importance in receiving and sending countries. The studies in question have highlighted a systemic relationship between ongoing globalization and the feminization of wage-labour (Sassen-Koob 1984). "Due to globalization, demand for female workers has been particularly strong, inducing girls and women to migrate into cities to work in domestic jobs and factories, later migrating abroad when dislocated by any number of hiccups in the global economy" (Mahler \& Pessar 2006: 46). The focus of these research studies includes the linkages among the structural forces underpinning globalization, the immigration process and the gendering of the incoming workforce (Kofman 2004). In this sense, the feminization of the labour market leads to the feminization of survival in the world, because productive systems can not operate without a reproductive system. The international division of reproductive work thus calls into question the 'market paradigm', and gives rise to a broader point of view on economic life, which can integrate both multiple forms of work and gender as factors controlling international migrations (Santamaría 2009). In other words, the globalization of production has been accompanied by the globalization of reproduction, a complex way in which gender, race and immigration interact (Calavita 2006), shaping migration patterns across the world and strengthening migrations by women, even in the face of the global economic crisis.

\section{The international migration of women rendering household services}

The domestic and care services (through which activities and relationships see nonfamily members involved in the promotion of people's physical and emotional well-being) have existed in most of the world since ancient times (Moya 2007), and have represented an important sector where the employment of immigrant women is concerned. From that point of view these activities could be labelled the 'classic immigrant woman's niche' (Schrover et al. 2007), though social and economic transformations associated with capitalism in the post-industrial period have altered its conceptualization and its dynamics, and 
women's migration can be seen as a combination of a crisis of care in the destination countries and a crisis of social reproduction in the countries of origin (Herrera 2012).

Domestic and care services have currently come to dominate much feminist research on globalised migrations, and have been interpreted as a transfer of labour from South to North that enables households to benefit from the migration of domestic workers and caregivers as they offer lower costs or greater flexibility in support of the productive system. In the case of the United States, for example, the prosperity of the 1990s led to what, using the words of Janet H. Momsen (1999), The Economist called the 'nanny bubble'. Consequently, gender, ethnicity and class must be analysed as interconnected constructs (Andall 2000). While paid domestic work is still a marginal issue on the political agenda, migrant women have come to play a crucial role in providing domestic and care services in the absence of welfare provision. As a result, the international movement of women who take up work as domestic workers, regardless of their differences in terms of citizenship, ethnicity or rural upbringing, now constitute a social 'other' subordinated directly to their employers and more generally to the urban host society, while migration itself has offered them certain opportunities derived from the fact that this work lies on the fuzzy border separating the private and public spheres.

\section{Household services and migratory patterns in Southern Europe}

The demand for immigrant women to work in household services in Spain cannot be split from the true nature of migration in Southern Europe, and it must be understood within the context of the social dumping that the combination of illegal immigration and the informal economy fosters (Baldwin-Edwards 1999; Godenau \& Zapata 2008). As Ribas-Mateos (2004: 1047) highlighted, social scientists should approach immigration issues from the threefold perspective of: changes in the employment structure caused by the informalization of the labour market; the conceptualization of the family in a context characterised by the 'two-fold presence' of women's work and the controversial role of the state in shaping economic and social relations (cuts in the provision of social services); particularly in defining policy networks in multi-level governance and in welfare-mix arrangements. Therefore, household services in Mediterranean countries - far from disappearing - have in fact experienced major expansion in the last few years, and have given rise to a new migratory pattern based on the feminization of flows (King \& Zontini 2000; Bettio et al. 2006).

Many authors have studied the role of this modality of migration in Spain, as it is the European country with the greatest number of female domestic workers, most of them immigrants (the number of legal domestic workers in Spain was approximately 400,000 in October 2012, 55\% of them foreigners). Different factors explain this circumstance. The first one entails the demographic changes brought about by population ageing; the rise in the average age of parents having their first child has further meant that an increasing number of people in paid employment, especially women, are taking responsibilities for two generations at the same time (Sarti 2006). The second factor is the increasing number of native women joining the paid labour force, both by necessity and by gradual emancipation, in what is known as the 'women's silent revolution'. This higher participation on labour markets has increased the demand for domestic and care services significantly. The third factor is that welfare policies aimed at balancing family life and the labour market have not been as well-developed in Spain as in Northern Europe, where state-sponsored child care and provisions for the elderly are the norm. This relative absence of social services has not been offset by a higher participation of native men in housework (including care work), a sign of the traditional patriarchal family values that have provided social protection in the past (thanks to women), and that contributed to a relatively undeveloped welfare state (Parella Rubio 2003). 
Consequently, the reconciling of work and family life in the case of many Spanish women has been achieved in part by an externalization of certain domestic tasks and of the care of dependants (Domínguez-Mujica \& Guerra Talavera 2009). The demand for domestic employees and service personnel has thus been met by immigrants, who are keen to work for lower salaries than native women, favouring the incorporation of reproductive work into the market. This trend towards the commodification of household services has given rise to a strong segmentation of immigrant women, who suffer a double segregation on the labour market, both from native women and male immigrants. The intersection of class, race and gender complicates considerably the nature of the role these migrant women play, contributing to their subordination and multiple marginalities (Calavita 2006). Many of them, for instance, are not entitled to be paid a minimum wage and have no right to taking maternity leave (ILO 2013). Complementarily, some researchers have demonstrated that the immigration of domestic workers and caregivers has had a positive effect on the size of the household services sector, and has led to a substantial increase in the labour supply of skilled native women, specifically in the time worked by women in highearnings occupations (about 2 hours per week on average) (Farré et al. 2009).

\section{Study sources}

This research has been supported by a quantitative analysis of data provided from different statistical sources. The most important of these are the National Statistical Institute (Spain) and the Spanish Ministry of Employment and Social Security. The former provides annual information on populations as broken down by gender, age, birthplace and nationality (Continuous Census Data Collection), and on population flows with the same references (Residential Variations Statistics). The source of these data is the Municipal register, the administrative register in which a municipality's inhabitants are recorded. The National Statistical Institute is also responsible for the
National Immigrant Survey of 2007, a macrosurvey whose aim was to study the demographic and social characteristics of those born abroad, as well as their migratory itineraries, work and residential history, family relations and relations with their country of origin and with Spanish society, at a time of maximum-intensity immigration into Spain.

From a demographic point of view, the information provided by the last Population and Housing Censuses (of 2011) will be very interesting indeed, although the first exploitation only provides information on population as broken down by gender, age, birthplace and nationality (census dissemination will be completed in December 2013, and should offer suitable data for the purpose of this research). Finally, the National Statistical Institute conducts and publishes, quarterly, the Economically Active Population Survey (EPA), whose main objective is the collection of data on the labour force (subdivided into the employed and unemployed), and on people outside the labour market. Likewise, the Spanish Ministry of Employment and Social Security offers monthly information regarding the national and foreign workers registered in the Social Security System by gender and sector of activity. A suitable combination of these substantial data sheds revealing light on the subject matter of this paper.

\section{The close relationship between economic evolution and immigration}

\section{Spanish economic expansion and immigrant women}

From the point of view of population mobility, global capitalism has led to an increase in the complexity of migration processes, as revolutionary developments in transport and means of communication, and new channels of information have given rise to what might be termed a world perspective making it possible for any country to potentially become a destination for emigrants and for migration flows to take place anywhere in the world (Vila-Belda 2007). For this reason, some 
authors regard mobility as a characteristic feature of a globalised economic system (Bergalli 2006).

In Spain, the rise in foreign immigration over the last fifteen years has been unprecedented, and has transformed the country into a major destination in the context of international labour mobility (Domínguez-Mujica et al. 2008). From 1986 on, both Spain's incorporation into the European Union and its process of convergence with its most-developed neighbour countries favoured the arrival of a new type of immigrant closely linked to the socioeconomic dynamic that coincided with the onset of a post-Fordist economic phase. Later (from the mid 1990s on), the consolidation of an economic model characterised by low productivity and rapid growth contributed to an intensification of migration flows. During this phase of expansion, development was based on a model dependent on highly flexible employment, such as in services and construction. In 2006, for example, most of the new jobs created in the services were associated with tourism or domestic service (30\%) (Royo 2009).

Since mobility flows have become much more female-dominated in the last few years, a gender perspective is essential to any understanding of them. As far as regions of origin are concerned, there is a remarkable heterogeneity among immigrant women, who reveal a wide variety of cultural references, experiences and motivations. However, Latin America has been the origin of the most important flows, since this emigration has for the most part been female in character. For example, $56 \%$ of the migrants leaving Peru in the last decade of the twentieth century were women (Altamirano 2004). In recent years, Latin American women have made up a greater proportion of employment-related migration, while earlier female migration to Spain was largely via family reunion. This can be interpreted in terms of, firstly, the acquisition by women of a certain level of freedom to move and, secondly, migration that results from previous, more permanent crises that neither the state of origin nor the destination state have been able to solve (Herrera 2012). Moreover, there has been a special preference shown for the hiring of Latin American women by Spanish households, on account of their being considered attentive, careful, loving and passive women, as reflected in the analysis of the discourses that appeal to the cultural affinity between Latin Americans and Spaniards (Triandafyllidou 2000).

From a quantitative point of view, the data reveal that the share of women in the total number of arrivals between 1998 and 2007 was $47 \%$, with no major changes being noted during this period. However, from the point of view of the different continents of origin, the evolution of the figures allows us to detect the predominance of women who arrived from America ahead of men and in connection with other geographical flows (Figs. 1 and 2).

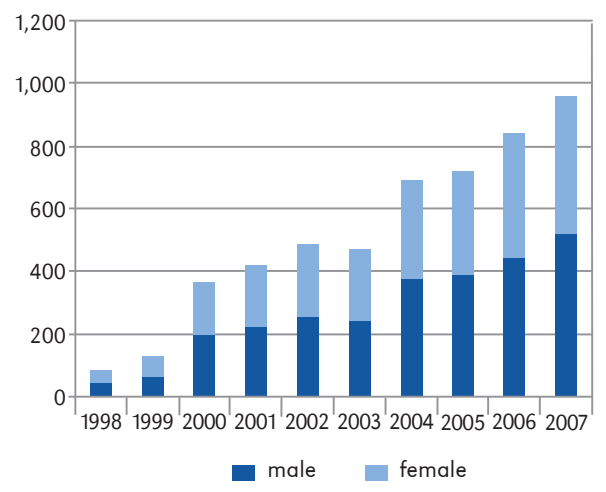

Figure 1. Immigration flows by gender (in thousand) Source: Residential Variations Statistic, compiled by the Instituto Nacional de Estadistica (INE).

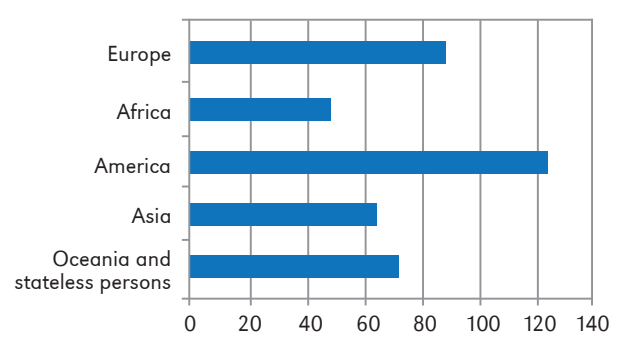

Figure 2. Number of women for every 100 men in inflows (1998-2007)

Source: Residential Variations Statistic, (INE). 
The composition by gender of the people arriving from Latin America reveals an important feminization of flows in the case of Paraguay, Brazil and the Dominican Republic (with over 150 women for every 100 men); a secondary level in the feminization of flows coming from Colombia, Bolivia, Cuba and Peru also becomes apparent (with figures between 140 and 120 women for every 100 men), whereas there is a more balanced share in the cases of Ecuador (an immigration flow with a predominant family pattern), Chile and Argentina (countries with a higher level of income and a more heterogeneous emigrant population), with figures between 98 and 104 women for every 100 men.

\section{The profile of Latin American immigrants in domestic service during the expansion phase of the economic cycle}

Many authors have highlighted how domestic work has played a key role in the social and labour integration of Latin American women (Díaz et al. 2012), but the statistical data show that this integration is characterised by a triple discrimination - based on gender, ethnos and class - that acts as a highly restrictive factor in terms of immigrants' choice (Santamaría 2009). The Immigrant National Survey (ENI) has been used as source of information by different researchers on this matter, the latter including Veira et al. (2011), who have provided a quantitative assessment of the impact of human capital, social capital and contextually related variables on the likelihood of working in the ethnic niche of domestic labour. We will use the same data (the sample of Latin American women who worked in Spain in household services in 2007) to determine these women's profiles.

3652 Latin American women were interviewed. 722 of them were engaged in domestic work during the survey reference week, $30.7 \%$ of those who had a job (2351); in the case of 1024 of them, domestic service had been their first occupation in Spain, and only 206 had been previously employed as domestic workers in their country of origin. Those whose first occupation in Spain had been as domestic workers and who continued to work in the domestic service sector numbered 320 (44\%), whereas the remaining 402 had changed jobs, finding employment in the hotel industry (145), in the commercial sector (73), in the real-estate sector (74) in healthcare or the social services (51), among others, or had simply stopped working. Conversely, those who started off in a different sector (808) and had later taken up employment in the domestic work sector only amounted to $9 \%$ of the former. This reinforces the view that domestic work is a marginal labour-market niche with little upward mobility, predominantly filled by Latin American immigrant women. This finding is also confirmed by the fact that $68 \%$ of the women who had worked as domestic workers in their country of origin continued to do so once they had arrived in Spain.

Most of the 722 women mentioned above had been born in Bolivia, Ecuador and Colombia, in proportions approximately equivalent to the female working population in those countries. According to the survey, their average age was high, 42, and their average level of educational attainment corresponded to secondary schooling, although many only had primary school qualifications. Figures were different in the cases of Argentinian and Chilean women (there were proportionally more of them in the sample as a whole and among women who worked than among those employed in domestic work), suggesting that the ethnification we have referred to varies according to the different levels of economic development in the Latin American countries of origin.

Only 31 women in this group claimed to have arrived in Spain with an employment contract; the others did not take long to find a job, as 374 of them said that they had found work within a month, and 230 within a period of between six months and a year. Regarding contract duration, the numbers of fixed term and open-ended contracts are practically the same; a quarter of them had been 
hired the year before, for a monthly pay that ranged between 500 and 999 euros (though most of them did not answer this question). $65 \%$ of them had more than one employment contract, but there is no clear correlation between the number of contracts and year of arrival, so that there are cases of women with a large number of contracts over a period of a few years and, conversely, others with a single contract over a period of many years.

Finally, the number of working hours varies enormously: 20 of those studied claimed to work 10 hours per week, 51 said they worked 20 hours per week, 173 mentioned 40 hours per week, and in many other cases the number of hours was even higher. These differences in the numbers of contracts and of hours worked reflect the wide range of situations to be found in the domestic-work sector (live-in domestic workers, contracts for few hours, different kinds of employers, etc.)

\section{The contraction phase in the Spanish economy and immigrant women}

Immigration flows have dropped markedly since the onset of recession in Spain (in 2007, at the height of the immigration flow, 958,266 new foreign residents were registered, as compared with 454,686 in 2011), and the number of foreign emigrants - most of them returnees - has increased (from 227,065 in 2007 to 370,540 in 2011). However, the number of residents born abroad is still very high (Fig. 3).

Every year new immigrants register with the municipal authorities; additionally, many of the older immigrants decide to stay because - even though the labour market is the central driver of migratory processes - there are other important factors that encourage mobility, such as housing, family, healthcare, education, the relationship between culture and religion or political and social commitments; in short, every aspect of society itself (Fernández \& Bueso 2005). Another element that must be considered as labour migration at a time of recession is analysed involves the different reactions immigrants display. Individuals

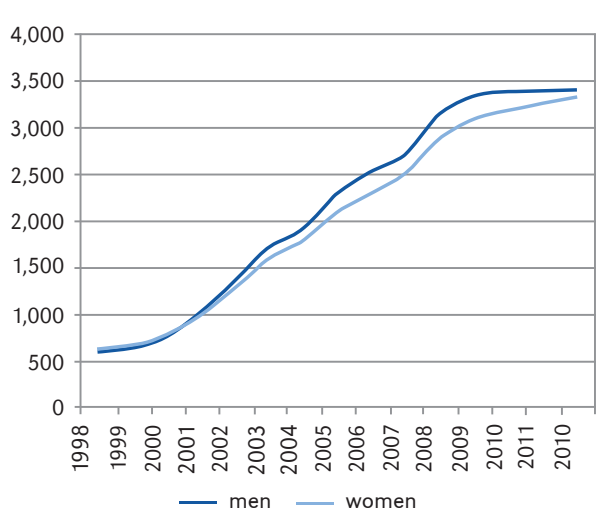

Figure 3. Trend for the stock of residents born abroad (in thousand)

Source: Exploitation of the Municipal Population Register, (INE).

differ in their behaviour, and each migrant's response is conditioned by multiple circumstances, among them their roots in the host community and their assessment of a potential return home (Domínguez-Mujica 2012).

The length of the stage of immigration in Spain, family connections and the role of different networks have contributed to the shaping of a moving landscape, as well as to the construction of linkages between different physical locations, as supporters of trans-nationalism claim. The transformation of many migrants into trans-migrants during the years of the expansion cycle has given rise to experiences lived that transcend the boundaries of nation-states, giving rise to multiple relationships - family, economic, social, organizational, religious and political - that extend beyond the borders from Spain to the countries of origin. In addition, there is growing recognition that developments in transportation and communications technologies, which have tended to increase as the crisis has continued, have brought about a qualitative transformation in the character of immigrant trans-nationalism, turning it into a far more dense and dynamic cross-border phenomenon than anything that would have been possible in earlier times (Portes \& DeWind 2004). 
Consequently, during the downturn, it is the multiple types of linkage built up during the previous economic stage that tend to condition migratory decisions. Figures indicate that the evolution of immigrant flows differs little between men and women (Fig. 4). Nevertheless, a slight increase can be detected in the share of women immigrants when all continents of origin are considered (Europe, 99 women per 100 men; Africa, 58; America, 133; Asia, 61 and Oceania, 81). This suggests that gender does play a greater role during a recession than during a phase of expansion, as the crisis has a lesser impact on the demand for domestic workers. Apart from this, the stronger ties with the physical location and closer family relationships in the case of women have favoured a greater flexibility in terms of mobility during the crisis (Domínguez-Mujica 2012). These transnational linkages built over the stage of expansion of the economic cycle left the door ajar for a possible return.

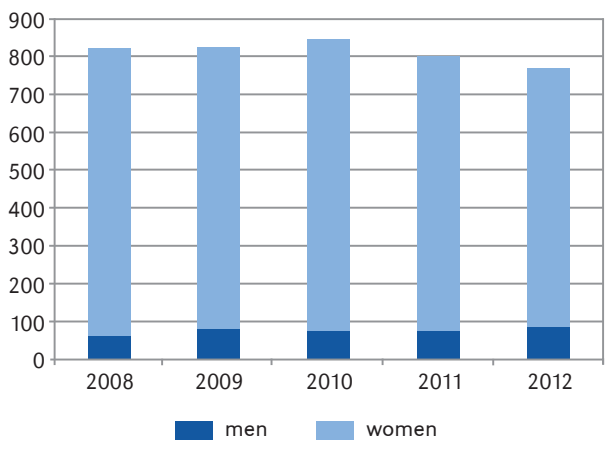

Figure 4. Number of active workers (in thousand) in the household services

Source: Active Population Survey.

\section{The resilience of household services in times of economic downturn}

Spain has become a privileged observatory when it comes to migration trends during a stage of economic crisis. The first findings from the investigations carried out are now starting to be published, and it is now possible to assess the evolution of the active population in the household services sector, and its relationship with the immigration of women (Consejo Económico y Social de España 2006; Domínguez-Mujica et al. 2012; de Villota et al. 2011). According to EPA data, the 2012 figure for people employed in household services represented $3.6 \%$ of the total active population and $7.7 \%$ of active women, both figures exceeding those in other Eurozone countries (Consejo Económico y Social de España 2009).

The evolution between 2007 and 2012 was slightly negative, and more noticeable in the case of women. They lost importance in absolute and relative terms, in comparison with both the total number of active women and the number of active men in that niche, although the sector continues to be very feminised (in 2008 for every 100 men there were 1200 women, and 2012 - 800) (Fig. 5).

From the point of view of women employed in the sector, the evolution is also negative. Nevertheless, the destruction of employment has been less intense than in other segments of the labour market, as the indexed figures for 2008 show (Fig. 5).

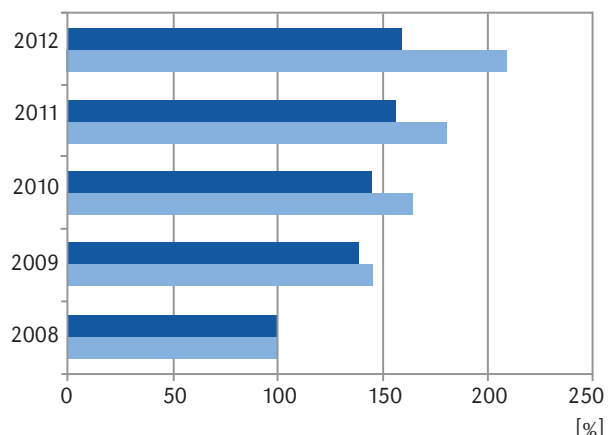

unemployed women in the household services total women unemployed

Figure 5. Indexed trend for unemployment among women

Source: Active Population Survey.

Among other factors, it is likely that Law 39/2006, which regulates assistance to dependent persons, has lessened the effect of unemployment on this sector because, according to the government, the norm was an 
excellent instrument for the creation of direct employment, estimated at 123,000 jobs (IMSERSO 2011). But, in fact, it is very complicated to interpret the evolution of figures because statistical information reflects only the visible part of this phenomenon, and the niche of household services in Spain is characterised by a high level of illegal employment (as is made clear by the differences between the number of active persons according to the Active Population Survey and the workers registered in this category with the Social Security System).

According to the EPA, the average figure for people active as domestic workers in 2012 was 768,500 , of which 658,900 were in employment. However, the Social Security System data show that, at the end of 2012, there were only 400,000 people registered as household workers (although it is possible that a few workers might have been registered in a general category or as selfemployed). This disparity led de Villota et al. (2011: 45) to estimate the number of irregular workers in this sector at 129,000 in 2010.

In spite of this degree of under-registration, the Social Security data allow us to characterize this phenomenon more accurately, because they have not been subject to the methodological modifications the EPA has undergone; they take account of all workers and not only of a sample, and they cover a lengthy temporal series (2000-2012). Figure 6 shows the evolution characterising Spanish and foreigners workers.

In this evolution we can track the intensity of labour immigration in the last few years. In 2000 the number of foreigners registered was 350,000 (2.3\% of the workers registered in Spain), as opposed to the two million registered in 2008 (more than 11\% of the total). The figure diminishes later on to a little over $1,600,000$, which represents $10 \%$, as a consequence of the parallel decrease in the registration of Spanish workers. Nevertheless, the drop in the number of foreigners has been greater (24\% as opposed to $15 \%$ ). This demonstrates the greater vulnerability of immigrant women and men, on account of their

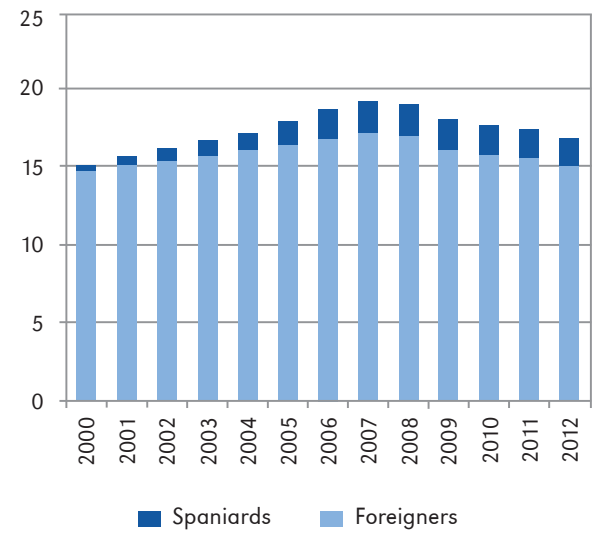

Figure 6. Workers registered with Spanish Social Security (in million)

Source: Ministry of Employment and Social Security.

higher levels of occupational segregation (Alonso-Villar \& del Río 2013). Consequently, Latin American nationals have displayed significant declines in their registrations with the Spanish Social Security system, and their registration as residents with the municipal authorities has increased very slightly or, has in some cases dropped (as with Ecuadorians, Bolivians and Argentinians). A relative economic recovery in these countries, in addition to voluntary return programmes and family savings after a prolonged period of working abroad, may have favoured the return of some of these people, especially the Ecuadoreans and Argentinians. We should also bear in mind that it is precisely the Latin Americans who have mostly acquired Spanish nationality, a circumstance facilitated by their greater integration into the host society and in turn a consequence of both the heritage of colonial bonds and the sharing of a common language (Domínguez-Mujica et al. 2012).

Regarding household services, foreigners continue to play a leading role. At the beginning of the series, $30 \%$ of all workers were foreign. As the years go by the composition of the sector becomes more ethnic-based (70\% in 2006 and 60\% in 2012, reflecting the 
impact of the crisis). This sequence is determined among other factors by the legal framework, as will be explained in the next section (Fig. 7).

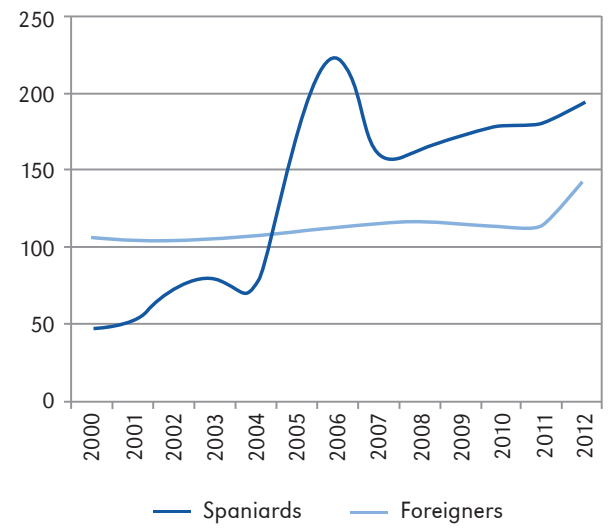

Figure 7. Household workers registered with Spanish Social Security (in thousand)

Source: Ministry of Employment and Social Security.

As was stated above, household services reflect what has been defined as a triple discrimination, by gender, ethnos and class. From this perspective, although foreign women represented $35 \%$ of the total number of foreigners at the beginning of the series and currently represent $47 \%$, the level of registration in the household services has been near to $90 \%$, as opposed to only $10 \%$ in the case of foreign men. The caretaking and domestic service sectors show a steady demand for labour since, despite the crisis, caretaking activities must always be engaged in, and the fact that Latin American female workers are characterised by a lower level of segregation than immigrant groups with higher educational attainments suggests that speaking a common language might favour this group in the case of household jobs, even if they are integrated into a secondary position in the labour market, in an ethnic niche. Therefore, despite the crisis, net employment in the domestic service sector has not decreased. Rather, there has been an increase in the supply of migrant women of other nationalities, and of Spanish women willing to take on these jobs.

The International Organization for Migrations claims that a high rate of unemployment among local women would prevent the hiring of immigrant women in the healthcare or people-care sectors (IOM 2009: 5-6), and immigrant women workers have also probably avoided returning to some extent because this would have involved the loss of economic independence acquired through migration, in turn possibly entailing a reversal of genderrole changes reflecting their mobility. The crisis has brought about a certain empowering of working women, for some immigrant families now depend exclusively on their income. However, at the same time, job insecurity, overcrowding in housing, the separation of families, and the paralysis of the migration plans of other family members all combine to create a sense of 'starting over again'. Moreover, they are being forced to seek more hours of paid labour, or to accept worse working conditions which they might have rejected before. Thus, despite the flexibility of arrangements possible in the care sector, during the crisis women's employment opportunities are constrained by the structural conditions of the labour market, the competition provided by Spanish women, and the persistent care obligations of their own. For example, for Ecuadorian migrants in Spain, it is as if the migratory process had become a circular experience, rather than one ensuring intergenerational social mobility, as was presumed just a few years ago (Herrera 2012).

\section{The legal framework of migration and household services}

Migratory processes and the linkages between immigration and the evolution of the labour market in household services are both conditioned by the legal framework. From a broader perspective, in Spain, as in other southern European countries, legislation has contributed to the consolidation 
of a migratory model characterised by mainly irregular flows. The reason for this entails, not just a scarcity of mechanisms that might facilitate legal immigration, but also the absence of effective means of inspection, and a lack of control in regard to the illegal hiring of foreign workers (Godenau 2007). Additionally, new regulations increasing the flexibility of working conditions in the secondary segment of the labour market have encouraged the temporary hiring of workers. It is consequently in this context that the widespread presence of immigrant workers in household services in Spain should be analysed. The economic crisis has favoured the introduction of legislation that curtails labour rights, with a consequent rise in the numbers of precarious jobs. On occasion, the development of a given law has been stalled, or the mechanisms for its application have met with difficulties, to the extent that the purpose is not served. This has been the case with Law 39/2006 mentioned above, intended to regulate the assistance to dependent persons, and whose inadequate application has failed to regulate the caregivers' job market successfully.

What follows is a brief summary of the laws and regulations that have played a decisive role as regards the immigration of Latin American women to work in household services. This confirms, in agreement with Riaño (2005), that the laws and regulations of highly industrialised countries have favoured migration by women. They have been divided into different categories.

\section{Laws and regulations that offer preferential treatment to certain communities of foreigners, and their impact on the ethno-stratification of immigration}

There is a range of legislation offering preferential treatment to flows from within the diaspora and/or from former colonies. This reveals a policy of preference for a shared cultural identity and homogeneity (Izquierdo Escribano et al. 2002) which has had a special impact in the case of Latin American immigrants. Article 17 of Law 36/2002 of the Civil Code facilitates an easier path to citizenship for descendants of Spanish emigrants, in that it confers Spanish nationality upon people born overseas to a Spanish mother or father, and allows them to apply for citizenship at any time, regardless of age. Further amendments of 2002 (Law 36/2002 of the Civil Code) and 2006 (Law 40/2006 of the Statute of Spanish Citizenship in Foreign Jurisdictions) further extended this privilege to the grandchildren of Spaniards. Article 22 of Law 36/2002 of the Civil Code reduces the 10-year period of legal residence required in Spain for naturalization to only two years in the case of Latin Americans and other nationalities with historical linkages with Spain. Finally, the possibility of acquiring Spanish nationality for reasons of exile, as reflected in Law 52/2007 (known as Law of 'Historical Memory'), has had a great impact on Latin American communities, especially among Cuban descendants of exiled Spaniards.

\section{Legislation that facilitates family reunification, and its impact on the migration of women}

In second place we have legislation that regulates the family reunification of immigrants. Article 17 of Organic Law 8/2000, on Foreigners' Rights and Freedoms in Spain and their social integration, as partially amended by Law 2/2011 regarding the reunification of relatives in the ascending line states that foreign residents have the right to regroup with them in Spain such close relatives as spouses, their own children and the children of their spouses, dependents and family members in the ascending line over 65 years of age. Many reunification processes in the case of Latin American foreigners have been led by women as heads of households, with the effect that the reunification process has affected children and husbands more than wives, especially in the case of Colombians, Bolivians, Paraguayans, etc. 


\section{Legislation that legalizes immigrants without authorization to work and settle in Spain, and its impact on the migration of non-skilled workers}

The most recent legislation legalising the situation of immigrants with no residence or work permit dates from 2000, 2001 and 2005. The first two correspond to the application of the decrees that developed Organic Law $8 / 2000$ as mentioned above. Following the first of these, 280,000 permits were granted. In the second case, 240,000 immigrants had their situation legalised on the basis of family reunification or long-term residence. Finally, the implementation of Royal Decree $2393 / 2004$, on the rights and freedoms of foreigners in Spain (Boletín Official del Estado of 7th January 2005), opened up a new opportunity for foreign workers to obtain legal status. During the subsequent process, known as 'normalization', over 690,000 applications for permits were submitted, of which 610,000 were granted.

The granting of permits favoured Latin American residents and especially domestic workers. As can be seen in Figure 7, the evolution in the number of workers registered showed a small increase in 2002-2003 and a significant rise in 2005, coinciding with the process of 'normalization'. However, this third process hid an underhand legalization of workers in other sectors of activity, or of inactive persons, especially women, who presented fictitious contracts declaring that they had been hired to do household work. It is thus necessary to treat the figures with caution, given the significant fall in registration between 2005 and 2007, after which a balance returns with a stabilization or slight increase in the figures through to 2011.

After that (post-2006), the Government provided a permanent channel for regularization through the Settlement Program, a new regulatory framework that makes the status of new migrants dependent on their labour activity, a policy that clearly poses the potential risk of a rise in the number of irregular migrants when the economic climate is unfavourable (Sabater \& Domingo 2012).

\section{Labour legislation, its half-hearted implementation and its impact on the migration of women to work in household services}

The most important legislation relevant to this study concerns work-permit quotas and specific legislation regulating household services. The quota is a process of individual authorization open to non-Community foreigners that is approved by the government and has its purpose the guaranteed meeting of demand for labour not met by Spanish workers. The Official Bulletin publishes a quarterly list of available positions. The most recent regulations introduced concerning the process, to elaborate this list of available positions, were established by Royal Decree 557/2011 (Boletín Official del Estado of 7th April 2011).

In the first quarter of 2008 the list encompassed 2300 available jobs. One and a half years later the figure had dropped to 160 jobs, while - in the last quarter of 2012 - the demand was only for eight jobs (excluding certain specialised jobs in the Merchant Navy sector, as well as other sports-related jobs authorised through an agreement with the State Secretary for Sport). At the same time, since the second quarter of 2008, household services have been disappearing as occupations without covering.

As regards legislation affecting domestic services specifically, from 1 January 2012 on the special Social Security category of Household Workers was integrated into the General Workers category as a special subcategory, in compliance with Law 27/2011 of 1 August, which updated, adapted and modernised the Spanish Social Security System in line with the Domestic Workers Convention, 2011 (No. 189), and the accompanying Recommendation (No. 201), adopted by the 100th Session of the International Labour Conference.

However, its implementation during 2012 threw up certain anomalies, as the revenue 
collected in social security contributions dropped, even though the number of contributors rose. This suggests that the obligation to pay per hour worked led to an increase in the number of paying workers, though only moderately so (Fig. 7) and in a manner far removed from that reflected in the EPA. Working days with very few working hours also came to light (or were at least registered as such). The government introduced new legal modifications in order to prevent further Social Security contribution revenue losses, among them specific regulations concerning workers hired to work for less than 60 hours a month per employer (in these cases it is the workers themselves who are responsible for their registration and deregistration with Social Security, and for communicating any relevant changes in their working status), as well as changes in the sizes of Social Security contributions payable by this sector. These modifications were approved by Royal Legislative Decree 29/2012, of 28 December (Boletín Official del Estado of 31st December 2012). This indicates that it was a procedure not undertaken, on account of the singularities introduced by a substantial share of immigrant workers into the already-complex and irregular domestic work sector (whose management is becoming more complex), and that far from bringing household workers closer to other sectors on the labour market it in fact tends to distance them again.

\section{Conclusions}

Our analysis has led us to a number of conclusions regarding immigrant domestic workers during a period of economic contraction, although our conclusions should be reassessed in the light of the evolution of the recession beyond 2013, as well as any new legislation that might affect this sector. Further qualitative research should also be undertaken, in line with certain ongoing research.

In the first place, competition for jobs between Spanish and foreign workers has intensified during these years of economic recession, though the latter (especially Latin
American women) have managed to hold on to a major share of the labour market. It should be borne in mind that, in addition to the persistence of foreign workers in this labour market niche, there are also Spanish nationals of foreign origin, particularly from Latin America, a fact that underlines one of the main characteristics of this sector, namely its ethnization.

Secondly, structural factors such as population ageing, the lesser development of social services and patriarchal family values, favour the externalization of reproductive work and contribute to consolidation of this labour niche. Consequently, the economic crisis has led, not so much to job destruction, as to greater job precariousness (longer working hours, lower pay, a return to live-in status, etc.). Apart from the vulnerability brought about by personal agreements not subject to labour regulations, there is also the instability caused by the death of elderly people caregivers look after, or the growth of the children they are responsible for, which forces them into frequent changes of employer. Despite this, steady demand ensures the availability of jobs in this niche, an exceptional circumstance when compared with other sectors of the secondary market hit so badly by the crisis.

Finally, a recognition that the existing legal framework is failing to regulate this sector. The economic crisis has slowed down the development of legislation, further testing the system's limitations. Per-hour contracts, particularly where families are trying to cut costs, the oral stipulation of specific working conditions and so on, all tend to heighten the degree of informality that is facilitating the employment of immigrant women. Moreover, as and when competition with Spanish workers increases, immigrant women are pushed into occupying worse segments of the labour market, as live-in workers with no contracts, or having to do more work in less time, or for lower pay. At the same time, many who took up jobs as domestic workers as a stepping stone to better prospects in Spain have seen their hopes of upward mobility fade away with the recession. 


\section{Acknowledgements}

The author would like to acknowledge the work of those participating in the discussions during the sessions of the SASE's 25th Annual Conference in Milan, 2013, and especially the suggestions of Profs. Dirk Godenau and Ana LópezSala. The author would also like to thank Prof.

\section{References}

Alonso-Villar O., del Río C., 2013. Occupational segregation in a country of recent mass immigration: Evidence from Spain. Annals of Regional Science, vol. 50, no. 1, pp. 109-134.

Altamirano T. 2004. Trasnacionalismo, remesas y economía doméstica. Cuadernos electrónicos de filosofía del derecho, no. 10, http://www. uv.es/CEFD [10 December 2013].

Andall J., 2000. Gender, migration and domestic service: The politics of black women in Italy. Interdisciplinary research series in ethnic, gender and class relations. Aldershot-HampshireBurlington: Ashgate.

Baldwin-Edwards M., Arango J. (eds.), 1999. Immigrants and the informal economy in Southern Europe. London: Frank Cass Publishers.

Bergalli R. (coord.), 2006. Flujos migratorios y su (des)control. Puntos de vista pluridisciplinarios. Rubí (Barcelona): Anthropos.

Bettio F., Simonazzi A., Villa P., 2006. Change in care regimes and female migration: The 'care drain' in the Mediterranean. Journal of European Social Policy, vol. 16, no. 3, pp. 271-285.

CALAVITA K., 2006. Gender, migration and law: Crossing borders and bridging disciplines. International Migration Review, vol. 40, no. 1, pp. 104-132.

Consejo Económico y Social de España, 2006. Panorama sociolaboral de la mujer en España. Las empleadas de hogar. Boletín elaborado por el Área de Estudios y Análisis, no. 43, pp.1-4.

Consejo Económico y Social de España, 2009. El empleo de la rama de hogares en la crisis: cuestionando algunos tópicos. Cauces: Cuadernos del Consejo Económico y Social, no. 10, pp. 22-33.

de Villota P., Herrero I.F., Cupeiro S.V., 2011. Impacto de la crisis económica en el trabajo
Marek Więckowski for his editing support, and her colleague Ramón Díaz-Hernández for his assistance with the review of this paper.

Editors' note:

Unless otherwise stated, the sources of tables and figures are the author(s), on the basis of their own research.

doméstico remunerado domiciliario y propuesta de medidas de políticas fiscal, social y laboral para estimular su formalización y profesionalización. Unión Europea y Ministerio de Sanidad, Servicios Sociales e Igualdad, http://www.inmujer.gob.es/en/observatorios/observlgualdad/ estudiosInformes/docs/impCrisisEcoTrabDomic. pdf [26 April 2013].

Díaz E.M., Gallardo F.C., Castellani S., 2012. Latin American immigration to Spain. Cultural Studies, vol. 26, no. 6, pp. 814-841.

Domínguez-Mujica J., 2012. Mobility in times of uncertainty: a geographical perspective, AGEl-Geotema, vol. 43-45, pp. 13-16.

Domínguez-Mujica J., Garcia Coll A., Gonzalez Perez J.M., Sanchez Aguilera D., 2008. La population étrangère en Espagne: quelques éléments d'une géographie changeante. Sud-Ouest Européen, no. 26, pp. 71-88.

Domínguez-Mujica J., Guerra Talavera R., 2009. The demographic transition and immigration flows in Spain: A close relationship. Geographical Review of Japan. Series B, vol. 81, no. 1, pp. 4-15.

Domínguez-Mujica J., Guerra-Talavera R., Parreño-Castellano J., 2012. Migration at a time of global economic crisis: The situation in Spain. International Migration Journal, article first published online: 29 November 2012.

Farré L., González L., Ortega F., 2009. Immigration, family responsibilities and the labor supply of skilled native women. Discussion Paper no. 4265. Bonn (Germany): Institute for the Study of Labor (IZA), 47 pp.

Fernández E.A., Bueso L.D., 2005. La participación política de los inmigrantes. Puntos de Vista. Cuadernos del Observatorio de las Migraciones y la Convivencia Intercultural de la Ciudad de Madrid (oMci), no. 2, pp. 7-20. 
GodenaU D., 2007. Inmigración y mercado de trabajo: una relación interactiva y dinámica [in:] J. C. Romero (ed.), Inmigración en Canarias: contexto, tendencias y retos. Santa Cruz de Tenerife: Fundación Pedro Gracía Cabrera, pp. 91-106.

Godenau D., HernándeZ, V.M.Z., 2008. Canarias: inmigración en una región fronteriza del sur de la Unión Europea. Política y sociedad, vol. 45, no. 1, pp. 61-83.

Herrera G., 2012. Starting over again? Crisis, gender, and social reproduction among Ecuadorian migrants in Spain. Feminist Economics, vol. 18, no. 2, pp. 125-148.

ILO, 2013. Domestic workers across the world: Global and regional statistics and the extent of legal protection. Genève: International Labour Organization.

IMSERSO, 2011. Informe del Gobierno para la evaluación de la Ley de Promoción de la Autonomía Personal y Atención a las personas en situación de dependencia. Madrid: Instituto de Mayores y Servicios Sociales, http://envejecimiento.csic. es/documentos/documentos/mspsi-evaluaciondependencia-01.pdf [30 October 2013].

IOM, 2009. Las repercusiones de la crisis económica mundial en los migrantes y en la migración. International Organization for Migrations, http://www.un.int/iom/Economic\%20Crisis\%20 March\%2009\%20Sp.pdf [4 April 2013].

Izquierdo Escribano A., López de Lera D., MartínEZ BuJÁn R., 2002. Los preferidos del siglo XXI: la inmigración latinoamericana en España [in:] J.F. García Castaño, C. Muriel López (eds.), Actas del III Congreso sobre la inmigración en España. Retos y Alternativas, Granada: Laboratorio de Estudios Interculturales, pp. 237-250.

KING R., ZONTINI E., 2000. The role of gender in the South European immigration model. Papers. Revista de Sociología, vol. 60, pp. 35-52.

Kofman E., 2004. Gendered global migrations. International Feminist Journal of Politics, vol. 6, no. 4, pp. 643-665.

KofMAN E., 2012. Rethinking care through social reproduction: Articulating circuits of migration. Social Politics, vol. 19, no. 1, pp. 142-162.

Mahler S.J., Pessar P.R., 2006. Gender matters: Ethnographers bring gender from the periphery toward the core of migration Studies. International Migration Review, vol. 40, no 1, pp. 27-63.
MOMSEN J., 1999. Maids on the move: Victim or victor [in:] J.H. Momsen (ed.), Gender, migration and domestic service. London-New York: Routledge, pp. 1-20.

MoROKVAsIC M., 1984. Birds of passage are also women. International Migration Review, vol. 18, no. 4, pp. 886-901.

MoYA J.C. 2007. Domestic service in a global perspective: Gender, migration and ethnic niches. Journal of Ethnic and Migration Studies, vol. 33, no. 4, pp. 559-579.

Parella Rubio S., 2003. Mujer, inmigrante y trabajadora: la triple discriminación. Rubí (Barcelona): Anthropos.

PESSAR P.R., 1984. The linkage between the household and workplace of Dominican women in the US. International Migration Review, vol. 18, no. 4, pp. 1188-1211.

Portes A., DeWInd J., 2004. A cross-Atlantic dialogue: The progress of research and theory in the study of international migration. International Migration Review, vol. 38, no. 3, pp. 828-851.

RIAÑo Y., 2005. Women on the move to Europe. A review of the literature on gender and migration [in:] M.G. da Marroni, G. Salgado (eds.), Latinamerican diaspora: Migration within a globalized world. Mexico: Autonomous University of Puebla, Japan: Institute of Developing Economies, Japan External Trade Organization, pp. 207-239.

Ribas-Mateos N., 2004. How can we understand immigration in Southern Europe? Journal of Ethnic and Migration Studies, vol. 30, no. 6, pp. 1045-1063.

Royo S., 2009. After the fiesta: The Spanish economy meets the global financial crisis. South European Society and Politics, vol. 14, no. 1, pp.19-34.

Sabater A., Domingo A., 2012. A new immigration regularization policy: The settlement program in Spain. International Migration Review, vol. 46, no. 1, pp. 191-220.

SANTAMARÍA L.C., 2009. La mercantilización y mundialización del trabajo reproductivo. El caso español. Revista de Economía Crítica, no. 7, pp. 74-94.

SARTI R., 2006. Domestic service: Past and present in Southern and Northern Europe. Gender \& History, vol. 18, no. 2, pp. 222-245.

SASSEN-KoOB S., 1984. From household to workplace: theories and survey research on migrant 
women in the labour market. International Migration Review, vol. 18, no. 4, pp. 1144-1167.

Schrover M., van der leun J., Quispel C., 2007. Niches, labour market segregation, ethnicity and gender. Journal of Ethnic and Migration Studies, vol. 33, no. 4, pp. 529-540.

Triandafyllidou A., 2000. The political discourse on immigration in Southern Europe: A critical analysis. Journal of Community and Applied Social Psychology, vol. 10, no. 5, pp. 373-389.
Veira A., Stanek M., Cachón L., 2011. Los determinantes de la concentración étnica en el mercado laboral español. La inmigración en España: perspectivas innovadoras. Revista Internacional de Sociología Revista Internacional de Sociología, vol. 69, no. M1, pp. 219-242.

VILA-BELDA J.A. 2007. Las migraciones internacionales en un mundo globalizado. Vanguardia dossier, no. 22, pp. 6-15. 